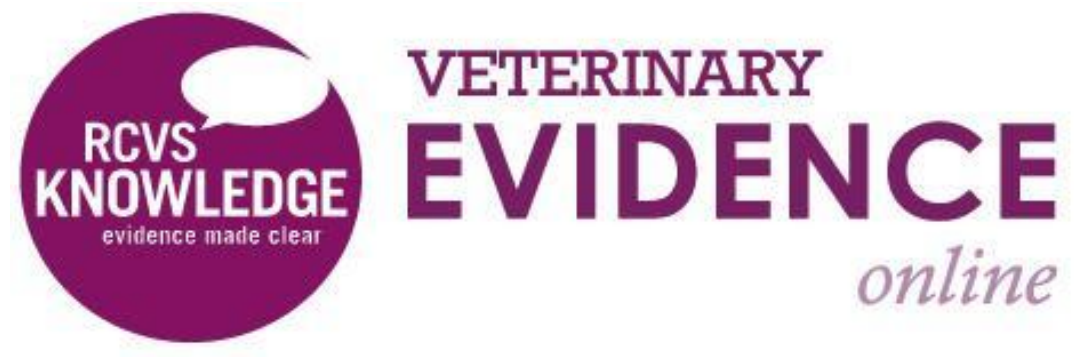

\title{
In Dogs With Traumatic Elbow Luxation, Does \\ Treatment Using Closed Reduction and Conservative Management Have a Better Prognosis Than Those Treated With Open Reduction and Surgery?
}

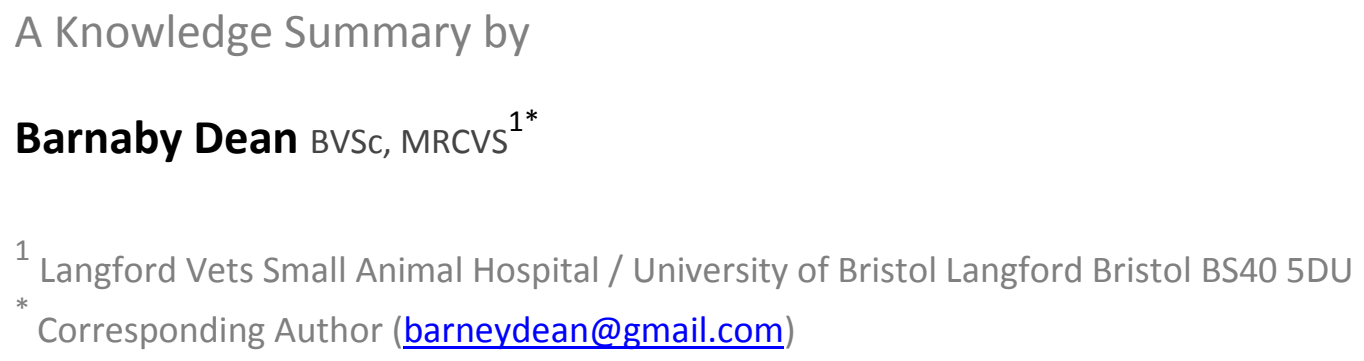

ISSN: 2396-9776

Published: 28 Nov 2017

in: Vol 2, Issue 4

DOI: http://dx.doi.org/10.18849/ve.v2i4.128

Reviewed by: Nina Kieves (DVM, DACVS-SA, DACVSMR, CCRT) and Stephen Jones (MVB, MS, DACVS) 
KNOWLEDGE SUMMARY

\section{Clinical bottom line}

In the available literature, cases of traumatic elbow luxation managed by closed reduction appear to have a better long-term prognosis than cases managed by open reduction and surgical stabilisation. That being said, it is important to consider that the poorer outcome in surgically-managed cases could reflect the severity or chronicity of the injury rather than the treatment method itself, or indeed could reflect a combination of the two.

Closed reduction of traumatic canine elbow luxation should be attempted in all cases as soon as possible as this is associated with a better prognosis. Should closed reduction not be possible, or should the elbow remain unstable or reluxate following closed reduction, surgical intervention is indicated. Joint immobilisation is recommended with either a Robert Jones bandage or splinted bandage for two-to-four weeks following treatment.

\section{Question}

In dogs with traumatic elbow luxation, does treatment using closed reduction and conservative management have a better prognosis than those treated with open reduction and surgery?

\section{Clinical Scenario}

A five-year-old, male, neutered Labrador Retriever presents to you with acute onset non-weight bearing left forelimb lameness following a road traffic accident. The left forelimb distal to the elbow is positioned laterally and is supinated. Palpation of the left elbow is moderately resented, and reveals severely disrupted skeletal anatomy. No other abnormalities are detected on clinical examination. Radiography of the left elbow reveals lateral elbow luxation and moderate soft tissue swelling. No other radiographic abnormalities are detected. Should closed reduction be attempted, or is surgical intervention indicated?

\section{Summary of the evidence}

\begin{tabular}{|r|l|}
\hline Billings (1992) & \multicolumn{2}{|l|}{} \\
\hline Population: & $\begin{array}{l}\text { Dogs and cats that suffered traumatic elbow luxation that were } \\
\text { referred to either the Veterinary Medical Teaching Hospital, } \\
\text { University of California, Davis, or to the Contra Costa Veterinary } \\
\text { Hospital between January } 1^{\text {st }} 1985 \text { and April } 30^{\text {th }} 1990 .\end{array}$ \\
\hline Sample size: & Nine dogs and one cat. \\
\hline Intervention details: & $\begin{array}{l}\text { Closed reduction was attempted and achieved in all canine } \\
\text { cases. }\end{array}$ \\
& $\begin{array}{l}\text { Six out of nine (67\%) reduced canine elbows were palpably } \\
\text { unstable following closed reduction, and open reduction and } \\
\text { surgical stabilisation was performed. A medial or lateral } \\
\text { approach to the elbow was made, and collateral ligaments and } \\
\text { muscle attachments were repaired by primary repair or with } \\
\text { bone anchor screws and figure-of-eight wire. The annular }\end{array}$ \\
&
\end{tabular}




\begin{tabular}{|c|c|}
\hline & $\begin{array}{l}\text { ligament was repaired in two cases. All cases had capsulorrhaphy } \\
\text { performed. } \\
\text { Of the surgically managed canine cases, three }(3 / 9,33 \%) \text { were } \\
\text { placed in a Spica splint for } 14 \text { days following surgery, and three } \\
\text { had Kirschner-Ehmer external fixators applied for seven to ten } \\
\text { days following surgery. The three non-surgically managed canine } \\
\text { cases were maintained in Spica splints for between seven and } \\
\text { ten days, and had exercise restricted. }\end{array}$ \\
\hline Study design: & Retrospective multi-centre (two) case series. \\
\hline Outcome studied: & $\begin{array}{l}\text { Follow-up veterinary examination was performed at the relevant } \\
\text { referral centres between six and } 53 \text { months following treatment (all } \\
\text { assessed subjectively): } \\
\text { - } \quad \text { Lameness: either yes or no, at walk or trot. } \\
\text { - Muscle atrophy compared to contralateral limb: either yes or no. } \\
\text { - Instability compared to contralateral limb: either yes or no. } \\
\text { - Range of motion: either abnormal or normal. } \\
\text { - Pain on palpation: either yes or no. } \\
\text { - } \quad \text { Joint thickening: either yes or no. } \\
\text { - Crepitation: either yes or no. } \\
\text { - Radiographic evidence of osteoarthritis: described briefly for } \\
\text { Results of client questionnaire at the time of follow-up (all assessed } \\
\text { subjectively): } \\
\text { - Return to work: either yes, no, or not applicable. } \\
\text { - Lameness after exercise: either yes or no. } \\
\text { - Regular use of analgesics: yes or no. } \\
\text { - Overall pleased with results: either definitely, somewhat, or } \\
\quad \text { displeased. }\end{array}$ \\
\hline $\begin{array}{l}\text { Main findings: } \\
\text { (relevant to PICO question): }\end{array}$ & $\begin{array}{l}\text { Closed reduction cases (three): one was a companion animal } \\
\text { which appeared clinically normal, one was a working dog that } \\
\text { returned to active hunting, experiencing mild lameness after } \\
\text { activity. Both had mild-to-moderate radiographic evidence of } \\
\text { osteoarthritis, and clients were satisfied with the outcome in } \\
\text { both cases. The third case had severe radiographic evidence of } \\
\text { osteoarthritis, continued lameness, moderate muscle atrophy, } \\
\text { required regular analgesia, and the client was unsatisfied with } \\
\text { the outcome. } \\
\text { Open reduction cases (six): in } 5 / 6 \text { (83\%) cases, lameness was } \\
\text { mild and intermittent, usually apparent after vigorous exercise, } \\
\text { degree of radiographic evidence of osteoarthritis was variable } \\
\text { (no further information provided); } 1 / 6 \text { (17\%) had extensive soft } \\
\text { tissue damage at the time of treatment, and showed evidence of } \\
\text { severe degenerative joint disease and required regular analgesia } \\
\text { at follow-up (53 months following treatment). } \\
\text { The authors considered the results from both groups to be } \\
\text { subjectively comparable, and postulate that severity of initial } \\
\text { injury, chronicity of luxation, patient size, and patient activity }\end{array}$ \\
\hline
\end{tabular}




\begin{tabular}{|c|c|}
\hline & level are important factors that contribute to outcome. \\
\hline Limitations: & $\begin{array}{l}\text { - It is a retrospective case series, which sits low on the hierarchy } \\
\text { of evidence. } \\
\text { - Cases are from } 1985 \text { to } 1990 \text {, meaning techniques and } \\
\text { medications may have changed during the study period and } \\
\text { since publication. } \\
\text { - Cases are provided from two centres, which may result in less } \\
\text { standardisation of treatment protocols. } \\
\text { - There is a small number of cases. } \\
\text { - } \quad \text { All outcome measures in both open and closed reduction groups } \\
\text { are subjective. } \\
\text { - There is no description of techniques used to determine } \\
\text { outcome measures i.e. degree of lameness, degree of } \\
\text { radiographic evidence of osteoarthritis. } \\
\text { - Time to follow-up is highly variable (between six and } 53 \text { months) } \\
\text { between cases, which may have influenced outcome measures. } \\
\text { Cases had all been referred from primary care veterinary clinics, } \\
\text { meaning an unrepresentative sample of more complicated and } \\
\text { difficult to manage cases may be included. } \\
\text { - Some outcome measures are listed on a two-point scale (e.g. } \\
\text { presence of lameness on a yes or no scale), when it may be } \\
\text { appropriate to record the outcome being measured on a multi- } \\
\text { point scale. } \\
\text { - Some outcome measures are based on client reports, not } \\
\text { veterinary examination. }\end{array}$ \\
\hline
\end{tabular}

\begin{tabular}{|c|c|}
\hline & \\
\hline Population: & $\begin{array}{l}\text { Dogs and cats brought to Istanbul University between } 1998 \text { and } \\
2004 \text { for management of traumatic elbow luxation. }\end{array}$ \\
\hline Sample size: & Seventeen dogs and five cats. \\
\hline Intervention details: & $\begin{array}{l}\text { - Seven canine cases managed by closed reduction followed by } \\
\text { coaptation with a Robert Jones bandage for one week, and } \\
\text { exercise restriction for four weeks. All seven cases were treated } \\
\text { within seven days of the causative injury. } \\
\text { - Ten canine cases managed by open reduction, augmented with } \\
\text { primary ligament repair, cortical screw bone anchors and } \\
\text { cerclage wire, and/or joint capsule repair as necessary (the } \\
\text { number of cases requiring each of these procedures is not } \\
\text { stated), followed by coaptation with a Robert Jones bandage for } \\
\text { one week, and exercise restriction for four weeks. All cases } \\
\text { treated by open reduction were considered 'chronic luxations'; } \\
\text { no further explanation is provided. }\end{array}$ \\
\hline Study design: & Retrospective single-centre case series. \\
\hline Outcome studied: & $\begin{array}{l}\text { Follow-up veterinary examination was performed at the referral } \\
\text { centre where surgery was performed between one month and two }\end{array}$ \\
\hline
\end{tabular}




\begin{tabular}{|c|c|}
\hline & $\begin{array}{l}\text { years following surgery: } \\
\text { - Joint stability; subjectively determined to be either stable or } \\
\text { unstable. } \\
\text { - Severity of radiographic osteoarthritis at follow-up examination } \\
\text { (one month to two years following surgery); subjectively } \\
\text { determined to be mild, moderate, or severe. } \\
\text { - Clinical outcome (lameness) at follow-up examination; } \\
\text { subjectively determined to be excellent, good, fair, or poor. }\end{array}$ \\
\hline $\begin{array}{l}\text { Main findings: } \\
\text { (relevant to PICO question): }\end{array}$ & $\begin{array}{l}\text { - In the closed reduction group at follow-up examination, joint } \\
\text { stability was achieved in } 6 / 7 \text { ( } 86 \% \text { ) cases; severity of } \\
\text { radiographic osteoarthritis was mild in } 5 / 7 \text { ( } 71 \%) \text {, moderate in } \\
1 / 7(14 \%) \text {, and severe in } 1 / 7 \text { cases; clinical outcome was } \\
\text { excellent in } 4 / 7 \text { ( } 57 \%) \text {, good in } 1 / 7(14 \%) \text {, fair in } 1 / 7 \text {, and poor in } \\
1 / 7 \text { cases. } \\
\text { - In the open reduction group at follow-up examination, joint } \\
\text { stability was achieved in } 9 / 10(90 \%) \text { cases; severity of } \\
\text { radiographic osteoarthritis was mild in } 3 / 10(30 \%) \text {, moderate in } \\
1 / 10(10 \%) \text {, and severe in } 6 / 10(60 \%) \text { cases; clinical outcome } \\
\text { was excellent in } 1 / 10(10 \%) \text { good in } 2 / 10(20 \%) \text {, fair in } 1 / 10 \text {, and } \\
\text { poor in } 6 / 10(60 \%) \text { cases. }\end{array}$ \\
\hline Limitations: & $\begin{array}{l}\text { - It is a retrospective case series, which sits low on the hierarchy } \\
\text { of evidence. } \\
\text { - Cases are from } 1998 \text { to } 2004 \text {, meaning techniques and } \\
\text { medications may have changed since publication. } \\
\text { - } \quad \text { There is a small number of cases. } \\
\text { - Outcomes studied are measured subjectively, which may } \\
\text { introduce bias. } \\
\text { - Insufficient detail is provided to enable accurate replication of } \\
\text { the study (e.g. the methods used to determine joint stability, } \\
\text { degree of radiographic osteoarthritis, and clinical outcome). } \\
\text { - Time to follow-up is not specified for each case, and varies wildly } \\
\text { (one month to two years), which alone may have affected } \\
\text { outcome. } \\
\text { - Insufficient information on patient group selection is provided - } \\
\text { the reader is only told that the groups consist of patients } \\
\text { presenting within the first week following injury, or are 'chronic'. }\end{array}$ \\
\hline
\end{tabular}

\begin{tabular}{|r|l|}
\hline \multicolumn{2}{|l|}{ McCartney (2010) } \\
\hline Population: & $\begin{array}{l}\text { Dogs that underwent surgical stabilisation of traumatic elbow } \\
\text { luxation following closed reduction between } 2003 \text { and } 2009 .\end{array}$ \\
\hline Sample size: & Ten dogs. \\
\hline Intervention details: & $\begin{array}{l}\text { All dogs were referred because the referring veterinary surgeon } \\
\text { could not reduce the elbow or could not maintain elbow in } \\
\text { reduction. }\end{array}$ \\
& $\begin{array}{l}\text { All dogs that presented following acute elbow luxation and were } \\
\text { found to have any degree of instability (defined as a range of }\end{array}$ \\
\hline
\end{tabular}




\begin{tabular}{|c|c|}
\hline & $\begin{array}{l}\text { movement beyond } 45 \text { degrees for medial rotations, and } 70 \\
\text { degrees for lateral rotation) underwent open stabilisation within } \\
\text { four days of the causative injury. } \\
\text { - All elbows were repaired using cortical screw bone anchors and } \\
\text { cerclage wire, with primary lateral collateral ligament repair as } \\
\text { necessary. } \\
\text { - A support bandage was applied for three days following surgery } \\
\text { in all cases. }\end{array}$ \\
\hline Study design: & Retrospective single-centre case series. \\
\hline Outcome studied: & $\begin{array}{l}\text { At follow-up client communication between six and } 60 \text { months } \\
\text { following surgery: } \\
\text { - Owner satisfaction; subjectively determined by client } \\
\text { questionnaire as very satisfied, satisfied, or not satisfied. } \\
\text { - Outcome; subjectively determined by unspecified authors based } \\
\text { on a combination of client questionnaire results to assess long- } \\
\text { term functional outcome and interpretation of clinical notes } \\
\text { (including follow-up examination and radiography between four } \\
\text { and six weeks following surgery) as either excellent (never stiff } \\
\text { or lame), good (intermittent stiffness or lameness), or poor } \\
\text { (frequently stiff or lame). }\end{array}$ \\
\hline $\begin{array}{l}\text { Main findings: } \\
\text { (relevant to PICO question): }\end{array}$ & $\begin{array}{l}\text { - Veterinary surgeon-assessed outcome was considered excellent } \\
\text { in } 2 / 10(20 \%) \text {, good in } 5 / 10(50 \%) \text {, and poor in } 3 / 10(30 \%) \text { cases. } \\
\text { - Owners reported that they were very satisfied with long-term } \\
\text { outcome in } 6 / 10(60 \%) \text {, and satisfied in } 4 / 10(40 \%) \text { cases. } \\
\text { - The authors suggest that elbow stability should be reassessed } 48 \\
\text { hours following closed reduction to determine if surgical } \\
\text { stabilisation is required. } \\
\text { - The authors state that bone anchor screws with figure-of-eight } \\
\text { wire, and primary ligament repair with nylon suture is an } \\
\text { effective means of surgical stabilisation of elbow luxation. } \\
\text { The authors state that, in general, traumatic elbow luxation } \\
\text { results in the majority of dogs suffering from clinically significant } \\
\text { stiffness or lameness. }\end{array}$ \\
\hline Limitations: & $\begin{array}{l}\text { - It is a retrospective case series, which sits low on the hierarchy } \\
\text { of evidence. } \\
\text { - Cases are from } 2003 \text { to } 2009 \text {, meaning techniques and } \\
\text { medications may have changed since publication. } \\
\text { - Cases are only provided from a single centre. } \\
\text { - There is a small number of cases. } \\
\text { - meanes had all been referred from primary care veterinary clinics, } \\
\text { difficult to manage cases may be included. } \\
\text { - The study only reports on a single patient group (those who } \\
\text { underwent surgical stabilisation following closed reduction), so a } \\
\text { comparison between treatment groups cannot be made. } \\
\text { Outcomes studied are measured subjectively using non- } \\
\text { validated metrology instruments, which may introduce bias. }\end{array}$ \\
\hline
\end{tabular}




\begin{tabular}{|l|l|}
\hline - Long-term outcome is determined based on client feedback \\
rather than veterinary assessment. \\
- Time to follow-up is highly variable (six to 60 months) between \\
cases, which may have influenced outcome, and there is no \\
attempt to correlate time-to-follow up and outcome \\
Despite cases presenting four-to-six weeks following surgery for \\
re-examination, findings are not reported for this.
\end{tabular}

\begin{tabular}{|c|c|}
\hline \multicolumn{2}{|l|}{ Mitchell (2011) } \\
\hline Population: & $\begin{array}{l}\text { Dogs and cats that presented to the Pet Emergency Room or } \\
\text { Queensland Veterinary Specialists for treatment of traumatic elbow } \\
\text { luxation between } 1999 \text { and } 2009 .\end{array}$ \\
\hline Sample size: & Fourteen dogs and 11 cats. \\
\hline Intervention details: & $\begin{array}{l}\text { - Closed reduction was attempted in all patients within three days } \\
\text { of the causative injury. } \\
\text { The elbows of three dogs whose elbows were severely unstable } \\
\text { after closed reduction re-luxated within } 24 \text { hours of closed } \\
\text { reduction and underwent open reduction. This was achieved } \\
\text { either via a medial approach to the elbow to repair the medial } \\
\text { collateral ligament using cortical screw bone anchors and a } \\
\text { figure-of-eight wire loop (in two dogs), or via a medial and lateral } \\
\text { approach to repair a torn medial and avulsed lateral collateral } \\
\text { ligament through primary ligament repair and by using a lag } \\
\text { screw at the avulsion site, respectively (in one dog). } \\
\text { External coaptation was employed in all cases, and was achieved } \\
\text { using either a Robert Jones bandage }(5 / 14,36 \% \text { ), light bandage } \\
\text { (2/14, } 14 \% \text { ), or Spica splint }(7 / 14,50 \%) \text { for between one day and } \\
\text { four weeks where recorded. }\end{array}$ \\
\hline Study design: & Retrospective multi-centre (two) case series. \\
\hline Outcome studied: & $\begin{array}{l}\text { At follow-up client communication between five months and nine } \\
\text { years following treatment (clients only responded in } 8 / 14,57 \% \text {, of } \\
\text { canine cases): } \\
\text { - Outcome; subjectively determined by client questionnaire as } \\
\text { either excellent (no noticeable lameness), good (infrequent } \\
\text { lameness), fair (persistent lameness), or poor (failure to use the } \\
\text { limb). } \\
\text { - Owner satisfaction; subjectively determined by client } \\
\text { communication as either satisfied, or not satisfied. }\end{array}$ \\
\hline $\begin{array}{l}\text { Main findings: } \\
\text { (relevant to PICO question): }\end{array}$ & $\begin{array}{l}\text { - Eight dog owners replied to the client questionnaire; six from } \\
\text { the closed reduction group, two from the open reduction group. } \\
\text { - Outcome was considered excellent in } 4 / 6(67 \%) \text {, good in } 1 / 6 \\
\text { (17\%), and fair in } 1 / 6 \text { closed reduction cases. Outcome was } \\
\text { considered fair in } 2 / 2(100 \%) \text { of open reduction cases. } \\
\text { - Owners considered themselves satisfied in all cases where } \\
\text { questionnaires were completed (8/8). }\end{array}$ \\
\hline
\end{tabular}




\begin{tabular}{|c|c|}
\hline & $\begin{array}{l}\text { - The authors consider joint stability following closed reduction to } \\
\text { be a positive prognostic indicator, and suggest closed reduction } \\
\text { should be attempted as soon as possible following injury. } \\
\text { Surgical management is advised in cases of persistent instability } \\
\text { following closed reduction (time frame is not specified), or in the } \\
\text { presence of avulsion fractures. }\end{array}$ \\
\hline Limitations: & $\begin{array}{l}\text { - It is a retrospective case series, which sits low on the hierarchy } \\
\text { of evidence. } \\
\text { - Cases are from } 1999 \text { and 2009, meaning techniques and } \\
\text { medications may have changed during the study period and } \\
\text { since publication. } \\
\text { - Cases are provided from two centres, which may result in less } \\
\text { standardisation of treatment protocols. } \\
\text { - There is a small number of cases. } \\
\text { - Cases are all reported from a referral hospital which may select } \\
\text { for more severe or difficult to treat cases (i.e. cases that } \\
\text { underwent satisfactory closed reduction were not referred). } \\
\text { - Outcomes studied are measured subjectively using non- } \\
\text { validated metrology instruments, which may introduce bias. } \\
\text { Outcome is measured solely by client feedback rather than } \\
\text { veterinary assessment. } \\
\text { Time to follow-up is highly variable (five months to nine years), } \\
\text { which may have influenced outcome. } \\
\text { There is significant variation in the duration of coaptation, which } \\
\text { may have influenced outcome. }\end{array}$ \\
\hline
\end{tabular}

\begin{tabular}{|c|c|}
\hline \multicolumn{2}{|l|}{ O’Brien (1992) } \\
\hline Population: & $\begin{array}{l}\text { Dogs with traumatic luxation of the cubital joint diagnosed at Angell } \\
\text { Memorial Animal Hospital and Tufts University School of Veterinary } \\
\text { Medicine, Foster Hospital for Small Animals from } 1978 \text { to } 1988 .\end{array}$ \\
\hline Sample size: & Forty-four dogs. \\
\hline Intervention details: & $\begin{array}{l}\text { Thirty-five ( } 80 \%) \text { dogs were treated with closed reduction, with } \\
\text { two of these cases requiring surgical repair of the medial } \\
\text { collateral ligament using a screw and spiked washer. } \\
\text { Nine }(20 \%) \text { dogs were treated with open reduction. Additional } \\
\text { surgical procedures performed at the time include: lateral } \\
\text { collateral ligament repair using non-absorbable, monofilament } \\
\text { suture ( } n=2) \text {; repair of the radial annular ligament using a } \\
\text { stainless-steel wire prosthesis ( } n=1) \text {; transarticular pinning to } \\
\text { maintain reduction for } 14 \text { days }(n=3) \text {. } \\
\text { External coaptation was employed in } 43 / 44(98 \%) \text { dogs with a } \\
\text { soft padded bandage ( } n=10), \text { Spica splint ( } n=7) \text {, cast ( } n=2) \text {, } \\
\text { Schroeder-Thomas splint ( } n=1) \text {, or an unspecified bandage } \\
\text { ( } n=23) \text {. Duration of coaptation was known in } 22 \text { cases, and } \\
\text { ranged from one day to six weeks (mean } 14 \text { days). }\end{array}$ \\
\hline Study design: & Retrospective multi-centre (two centres) case series. \\
\hline
\end{tabular}




\begin{tabular}{|c|c|}
\hline Outcome studied: & $\begin{array}{l}\text { Follow-up client communication and/or veterinary assessment was } \\
\text { performed between three and } 137 \text { months following treatment and } \\
\text { involved: } \\
\text { - In all } 44 \text { dogs: result of treatment; determined subjectively by } \\
\text { client telephone contact as either excellent (no detectable } \\
\text { lameness), good (infrequent weight-bearing lameness, especially } \\
\text { after exercise or inclement weather), fair (frequent episodes of } \\
\text { lameness), and poor (marked non-weight bearing lameness with } \\
\text { abnormal limb function). } \\
\text { - In all } 44 \text { dogs: client satisfaction; determined subjectively by } \\
\text { client telephone contact as either satisfied or unsatisfied. } \\
\text { In the } 6 / 44 \text { (14\%) of dogs available for follow-up veterinary } \\
\text { examination: gait evaluation, limb function and range of motion } \\
\text { as determined by physical examination, and radiographic } \\
\text { evidence of osteoarthritis, determined subjectively by veterinary } \\
\text { assessment. }\end{array}$ \\
\hline $\begin{array}{l}\text { Main findings: } \\
\text { (relevant to PICO question): }\end{array}$ & $\begin{array}{l}\text { - Closed reduction group: outcome was rated by clients as } \\
\text { excellent in } 27 / 35 \text { ( } 77.1 \%) \text { cases, } 4 / 35(11.5 \%) \text { good, } 2 / 35(5.7 \%) \\
\text { fair, } 2 / 35 \text { poor. } 33 / 35 \text { ( } 94 \%) \text { of clients were satisfied with the } \\
\text { outcome. } \\
\text { Open reduction group: outcome was rated by clients as } \\
\text { excellent in } 1 / 9 \text { (11.2\%) cases, } 4 / 9(44 \%) \text { good, } 4 / 9 \text { fair. } 9 / 9 \\
\text { ( } 100 \%) \text { of clients were satisfied with the outcome. } \\
\text { Six dogs presented for veterinary assessment, four from the } \\
\text { closed reduction and two from the open reduction group. Closed } \\
\text { reduction: } 4 / 4 \text { ( } 100 \%) \text { showed no detectable lameness } \\
\text { andoutcome was rated excellent by the clients; } 2 / 4(50 \%) \\
\text { showed mild reduction in range of movement and mild } \\
\text { radiographic osteoarthritic change, } 50 \% \text { showed no reduction in } \\
\text { range of movement and no evidence of radiographic } \\
\text { osteoarthritic change. Open reduction: } 2 / 2 \text { (100\%) were lame at } \\
\text { walk and outcome was rated fair by the clients; range of } \\
\text { movement was decreased in both cases, and there was evidence } \\
\text { of severe radiographic osteoarthritic change in both cases. }\end{array}$ \\
\hline Limitations: & $\begin{array}{l}\text { - It is a retrospective case series, which sits low on the hierarchy } \\
\text { of evidence. } \\
\text { - Cases are from } 1978 \text { to } 1988, \text { meaning techniques and } \\
\text { medications may have changed during the study period and } \\
\text { since publication. } \\
\text { - Cases are only provided from multiple centres, meaning there is } \\
\text { likely to be reduced standardisation of care. } \\
\text { - There is a small number of cases. } \\
\text { - Most outcomes studied are measured subjectively, which may } \\
\text { introduce bias. } \\
\text { - Time to follow-up is highly variable between and within patient } \\
\text { groups making direct comparisons difficult. } \\
\text { Joint immobilisation method and duration is highly variable, and } \\
\text { includes transarticular pinning as one of the options, which may } \\
\text { affect outcome. }\end{array}$ \\
\hline
\end{tabular}




\begin{tabular}{|c|c|}
\hline \multicolumn{2}{|l|}{ Pass (1971) } \\
\hline Population: & $\begin{array}{l}\text { Dogs presented to Ontario Veterinary College with traumatic elbow } \\
\text { luxation between } 1966 \text { and } 1970 \text { ( } 12 \text { cases identified, but only two } \\
\text { cases reported) }\end{array}$ \\
\hline Sample size: & Two dogs. \\
\hline Intervention details: & $\begin{array}{l}\text { - Closed reduction was performed in both cases. } \\
\text { - An unspecified bandage was applied in both cases (for } 12 \text { days in } \\
\text { case } 1 \text { and two days in case } 2 \text { ). } \\
\text { - Exercise was restricted in case } 2 \text { for seven days. Exercise } \\
\text { restriction was not reported for case } 1 \text {. }\end{array}$ \\
\hline Study design: & Retrospective single-centre case series. \\
\hline Outcome studied: & $\begin{array}{l}\text { - Clinical outcome; determined subjectively by veterinary } \\
\text { assessment at unspecified times following closed reduction, and } \\
\text { by client communication at either six weeks (case 1) or eight } \\
\text { weeks (case } 2 \text { ) following closed reduction. }\end{array}$ \\
\hline $\begin{array}{l}\text { Main findings: } \\
\text { (relevant to PICO question): }\end{array}$ & $\begin{array}{l}\text { Case 1: the dog was weight-bearing lame on the affected limb } \\
\text { after bandage removal, and the client reported intermittent } \\
\text { lameness on the affected limb six-weeks following bandage } \\
\text { removal. } \\
\text { Case 2: the dog underwent veterinary assessment at two } \\
\text { unspecified times following discharge where no outcome is } \\
\text { reported, and the client reported no evidence of lameness eight } \\
\text { weeks following bandage removal. }\end{array}$ \\
\hline Limitations: & $\begin{array}{l}\text { - It is a retrospective case series, which sits low on the hierarchy } \\
\text { of evidence. } \\
\text { - Cases are from } 1966 \text { to } 1970 \text {, meaning techniques and } \\
\text { medications may have changed during the study period and } \\
\text { since publication. } \\
\text { - Cases are only provided from a single centre. } \\
\text { - There is a small number of cases, and there is no explanation or } \\
\text { rationale provided for the selection criteria for the two } \\
\text { presented cases out of } 12 \text { cases identified. } \\
\text { - Follow up is described in extremely limited detail and reporting } \\
\text { is not standardised between cases. } \\
\text { - Outcome is measured subjectively, and is partly measured based } \\
\text { on client reporting using non-validated reporting systems. } \\
\text { Management post closed reduction varies between cases, and } \\
\text { no explanation is provided for this. }\end{array}$ \\
\hline
\end{tabular}

Sajik (2016)

Population: Dogs referred to The Queen Mother Hospital for Animals at the Royal Veterinary College, Small Animal Hospital at the University of Glasgow, Small Animal Specialist Hospital in Sydney, Veterinary Specialist Centre Sydney, and Anderson Moores Veterinary Specialists for management of traumatic elbow luxation between 
2006 and 2013.

\begin{tabular}{|c|c|}
\hline & 2006 and 2013. \\
\hline Sample size: & Thirty-seven dogs. \\
\hline Intervention details: & $\begin{array}{l}\text { - Seventeen dogs were managed with closed reduction alone. } \\
\text { - Twenty dogs underwent surgical management. Indications for } \\
\text { surgical management were inability to perform closed reduction, } \\
\text { or persistent instability or reluxation following closed reduction. } \\
\text { No case had open reduction without concurrent stabilisation. } \\
\text { Surgical stabilisation was grouped into the following categories: } \\
\text { a) circumferential suture prosthesis through transcondylar bone } \\
\text { tunnels ( } n=11 \text { ), b) bone anchor screw placement with prosthetic } \\
\text { ligament/orthopaedic wire placement ( } n=4) \text {, c) bone anchor } \\
\text { screw placement with prosthetic ligament plus circumferential } \\
\text { suture ( } n=1), d \text { ) bone anchor screw with prosthetic ligament plus } \\
\text { transarticular pin ( } n=1 \text { ), e) bone anchor screw placement with } \\
\text { prosthetic ligament plus transarticular external skeletal fixator } \\
\text { ( } n=1), f \text { ) open reduction plus transarticular external skeletal } \\
\text { fixator ( } n=1 \text { ), g) closed reduction plus transarticular external } \\
\text { skeletal fixator ( } n=1 \text { ). } \\
\text { Post-reduction, external coaptation or fixation was employed in } \\
30 \text { cases; Spica splint in } 20 \text { cases (10 closed, } 10 \text { surgical), } \\
\text { cast/bandage in seven cases (four closed, three surgical), } \\
\text { transarticular external skeletal fixator in three cases (one closed, } \\
\text { two surgical). Duration of external coaptation is not listed. }\end{array}$ \\
\hline Study design: & Retrospective multi-centre (five centres) case series. \\
\hline Outcome studied: & $\begin{array}{l}\text { Quality of life, limb pain, and limb function; assessed subjectively } \\
\text { by clients using a validated metrology instrument (Canine Brief } \\
\text { Pain Index Questionnaire, Brown et al 2008). This includes four } \\
\text { questions that grade severity of the dog's pain over the previous } \\
\text { seven days (rated 0/no pain, to 10/extreme pain), six questions } \\
\text { that evaluate limb function over the previous seven days (rated } \\
\text { 0/no interference, to 10/extreme interference), and one } \\
\text { question to assess overall quality of life (rated poor, fair, good, } \\
\text { very good, or excellent). }\end{array}$ \\
\hline $\begin{array}{r}\text { Main findings: } \\
\text { (relevant to PICO question): }\end{array}$ & $\begin{array}{l}\text { Quality of life of patients at the time of follow-up client } \\
\text { questionnaire (mean } 961 \text { days [+/-849 days]) following treatment: } \\
\text { - Closed reduction: quality of life rated excellent in } 4 / 9(44 \%) \text { of } \\
\text { cases, very good in } 4 / 9 \text { cases, fair } 1 / 9(11 \%) \text { cases; mean pain } \\
\text { score is reported as } 0.19 / 10 \text { (range } 0-1.25) \text {; mean limb function } \\
\text { is reported as } 0.80 / 10 \text { (range } 0-4.67) \text {. } \\
\text { - Surgical intervention: quality of life rated excellent in } 9 / 12 \\
\text { (75\%) cases, very good in } 2 / 12(17 \%) \text { cases, good in } 1 / 9(11 \%) \\
\text { cases; mean pain score is reported as } 0.90 / 10 \text { (range } 0-3.75) \text {; } \\
\text { mean limb function is reported as } 0.96 / 10 \text { (range } 0-3.83) \text {. } \\
\text { Major post-operative complications occurred in } 7 / 37(19 \%) \\
\text { cases: reluxation ( } n=6) \text { and infection required implant removal } \\
\text { (n=1). }\end{array}$ \\
\hline
\end{tabular}




\begin{tabular}{|c|c|}
\hline & $\begin{array}{l}\text { - Five reluxations occurred following closed reduction; one was } \\
\text { successfully managed with repeat closed reduction, three were } \\
\text { surgically stabilised (and included in the surgical group), one was } \\
\text { euthanased due to severity of disease. One reluxation occurred } \\
\text { following surgical stabilisation with lateral screw and medial } \\
\text { prosthetic ligament placement, revision surgery was performed } \\
\text { successfully using the same technique. } \\
\text { Four of the six reluxations occurred in patients with dogs } \\
\text { suffering from concurrent orthopaedic injuries in other limbs. }\end{array}$ \\
\hline Limitations: & $\begin{array}{l}\text { - It is a retrospective case series, which sits low on the hierarchy } \\
\text { of evidence. } \\
\text { - Cases are from } 2006 \text { and 2013, meaning techniques and } \\
\text { medications may have changed during the study period and } \\
\text { since publication. This is highlighted in the discussion, as a new } \\
\text { surgical technique was described by Farrell et al. (2009) that was } \\
\text { employed later in the present study (data presentation prevents } \\
\text { correlation of outcome with surgical method employed). } \\
\text { - Cases are provided from five centres, which may result in less } \\
\text { standardisation of treatment protocols. } \\
\text { - There is a small number of cases. } \\
\text { - Cases are all reported from referral hospitals which may select } \\
\text { for more severe or difficult to treat cases (i.e. cases that } \\
\text { underwent satisfactory closed reduction were not included). } \\
\text { Outcomes studied are measured subjectively by clients rather } \\
\text { than by veterinary assessment, which may introduce bias. The } \\
\text { metrology instrument used is validated, however. } \\
\text { - There is no mention of duration of coaptation, but it is described } \\
\text { as variable, which may have influenced outcome. } \\
\text { Time to follow-up is highly variable (961 +/- } 849 \text { days) between } \\
\text { cases, which may have influenced outcome. } \\
\text { There is variation in the surgical techniques used within the } \\
\text { surgically managed group of patients, which may have } \\
\text { influenced outcome. } \\
\text { Patients with concurrent orthopaedic injuries to other limbs } \\
\text { were included in the study, which may have influenced } \\
\text { outcome. The authors state that four out of the six reluxations } \\
\text { occurred in these patients. }\end{array}$ \\
\hline
\end{tabular}

Schaeffer (1999)

\begin{tabular}{|c|c|}
\hline Population: & $\begin{array}{l}\text { Dogs with traumatic elbow luxation presented to Utrecht University } \\
\text { Faculty of Veterinary Medicine between } 1984 \text { and } 1996 .\end{array}$ \\
\hline Sample size: & Thirty-one dogs. \\
\hline Intervention details: & $\begin{array}{l}\text { Nineteen dogs with acute lateral luxation were treated with } \\
\text { closed reduction, and joint stability was assessed using } \\
\text { Campbell's method. One collateral ligament (specific ligament } \\
\text { not stated) was sutured following closed reduction in four of } \\
\text { these dogs. Joint immobilisation was achieved with application } \\
\text { of a Spica splint, lightweight bandage, or Robert Jones bandage }\end{array}$ \\
\hline
\end{tabular}




\begin{tabular}{|c|c|}
\hline & $\begin{array}{l}\text { for a mean of } 25 \text { days (range two to } 42 \text { days). Exercise restriction } \\
\text { was recommended for two weeks. } \\
\text { One dog with acute bilateral luxation and two dogs with chronic } \\
\text { elbow luxation were treated with open reduction. Joint } \\
\text { immobilisation was achieved with application of a Spica splint or } \\
\text { lightweight bandage for one to four weeks. } \\
\text { - Five dogs had a Monteggia fracture; these cases are excluded } \\
\text { here as they are considered beyond the scope of this Knowledge } \\
\text { Summary. } \\
\text { Three dogs with chronic (four weeks to one year) elbow } \\
\text { subluxation received no treatment, and one dog had an acute } \\
\text { lateral luxation and was euthanised at the owner's request; } \\
\text { these cases are excluded from this Knowledge Summary. }\end{array}$ \\
\hline Study design: & Retrospective single-centre case series. \\
\hline Outcome studied: & $\begin{array}{l}\text { Follow-up reported subjectively from between four months and nine } \\
\text { years (mean } 35+/-22 \text { months) following treatment in } 24 / 31(77 \%) \\
\text { of cases (three patients received no treatment; one was euthanised } \\
\text { at presentation; three were lost to follow up - two from the closed } \\
\text { reduction group, one from the open reduction group): } \\
\text { - Owner's opinion: reported as very satisfied, satisfied or } \\
\text { unsatisfied. } \\
\text { - Clinical results, determined based on: decrease in range of } \\
\text { movement (none, slight, moderate, or severe); degree of } \\
\text { osteoarthritis as assessed by the referring veterinary surgeon or } \\
\text { by a member of the university's veterinary radiology department } \\
\text { (none, slight, moderate, or severe); activity after treatment } \\
\text { (reported as normal, slightly decreased, or decreased); lameness } \\
\text { (reported descriptively, with further quantification as none, mild, } \\
\text { moderate, or severe). }\end{array}$ \\
\hline $\begin{array}{l}\text { Main findings: } \\
\text { (relevant to PICO question): }\end{array}$ & $\begin{array}{l}\text { - Closed reduction had been attempted by the referring } \\
\text { veterinary surgeon in nine cases, but this had failed in six cases, } \\
\text { and resulted in severe subluxation in three cases. } \\
\text { Closed reduction (outcome available in } 17 \text { cases): clinical results } \\
\text { are reported as excellent in five ( } 29 \% \text { ) cases, good in three (18\%) } \\
\text { cases, fair in six ( } 35 \% \text { ) of cases, and poor in three cases. The } \\
\text { elbow was stable in } 10 \text { (59\%) of these cases, and these were the } \\
\text { only cases to achieve excellent or good outcome. Moderate-to- } \\
\text { severe osteoarthritic changes were identified in } 10 \text { (59\%) of } \\
\text { cases. Clients are reported as very satisfied in } 10 \text { (59\%) cases, } \\
\text { satisfied in } 5 \text { ( } 29 \% \text { ) cases, and unsatisfied in } 2(12 \%) \text { cases. Four } \\
\text { (24\%) cases were operated on later (nine days following closed } \\
\text { reduction in one case, timing of surgery unspecified in two } \\
\text { cases) to repair collateral ligaments or remove periarticular } \\
\text { bone fragments, and outcome is only reported following } \\
\text { surgery. The influence of joint instability after closed reduction } \\
\text { on poor clinical result is considered significant (p>0.05). } \\
\text { Open reduction (outcome available in two cases / three elbows, }\end{array}$ \\
\hline
\end{tabular}




\begin{tabular}{|c|c|}
\hline & $\begin{array}{l}\text { one case suffered bilateral elbow luxation): Clinical results are } \\
\text { reported as good in } 1 \text { (33\%) elbow, fair in } 1 \text { elbow, and poor in } 1 \\
\text { elbow. } \\
\text { The presence of an avulsion fracture did not seem to influence } \\
\text { joint instability. } \\
\text { - Indications for surgical management include chronic luxations, } \\
\text { reluxation, and the necessity to remove bony fragments. }\end{array}$ \\
\hline Limitations: & 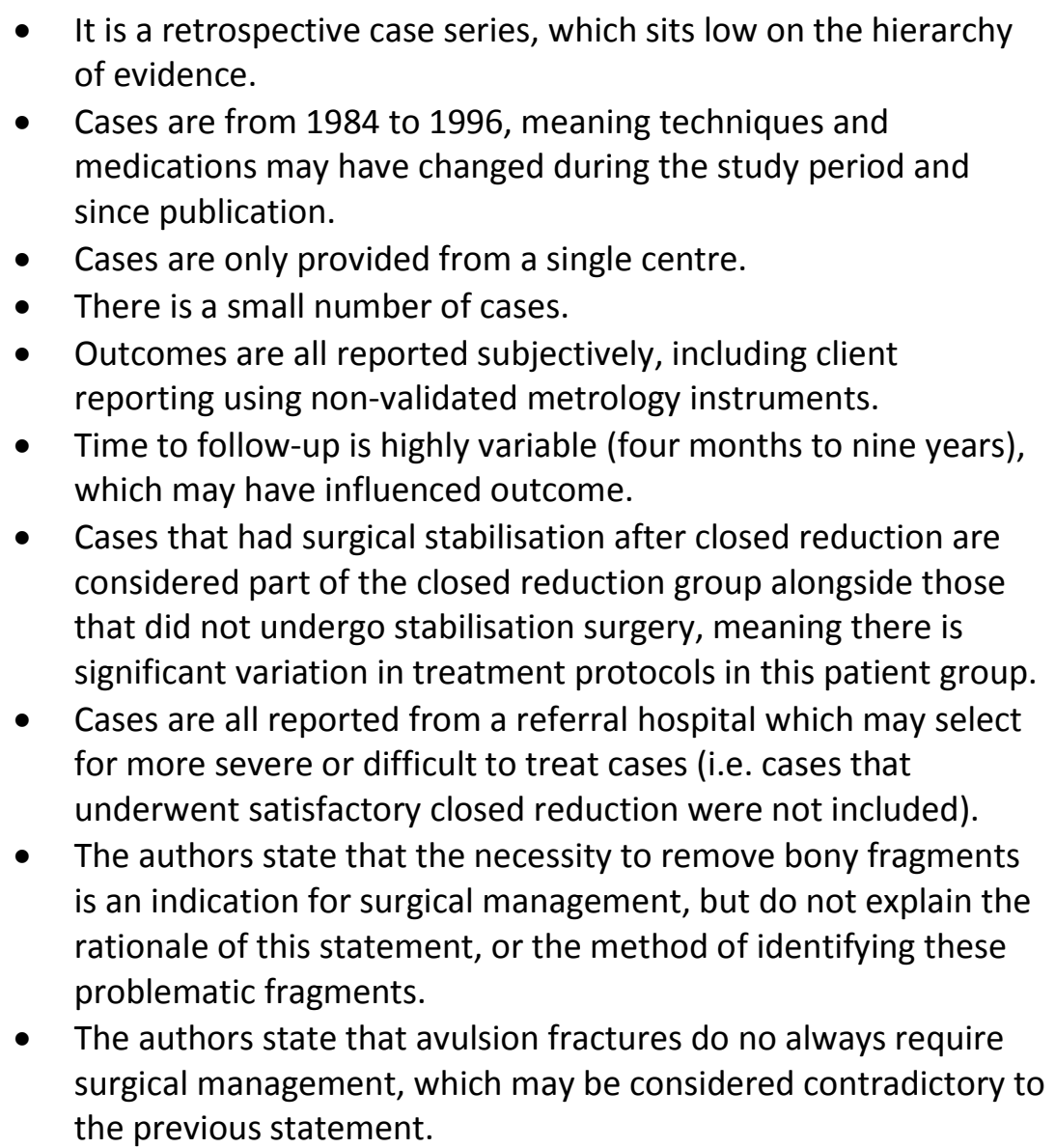 \\
\hline
\end{tabular}

\begin{tabular}{|c|l|}
\hline \multicolumn{2}{|l|}{ Vedrine (2017) } \\
\hline \multicolumn{2}{|l|}{ Population: } \\
& $\begin{array}{l}\text { Canine and feline patients treated at the veterinary clinic Seinevet, } \\
\text { Rouen-Boos, France, for traumatic elbow luxation or triceps muscle } \\
\text { avulsion with elastic transarticular external fixator between May } \\
2013 \text { and December } 2014 .\end{array}$ \\
\hline Sample size: & $\begin{array}{l}\text { Two dogs and two cats treated for elbow luxation, one dog treated } \\
\text { for triceps tendon avulsion. }\end{array}$ \\
\hline Intervention details: & $\begin{array}{l}\text { All patients underwent closed elbow reduction and had residual } \\
\text { joint instability diagnosed using Campbell's test. } \\
\text { All patients underwent the elastic transarticular external fixator } \\
\text { technique. This involves surgical placement of a transverse pin in } \\
\text { the distal quarter of the humerus, and another in the centre of } \\
\text { the olecranon. The pins are connected by medially and laterally } \\
\text { placed rigid connecting bars with the joint held at } 140^{\circ} \text { for two } \\
\text { days. After two days, the connecting bar is replaced with tight }\end{array}$ \\
\hline
\end{tabular}




\begin{tabular}{|c|c|}
\hline & $\begin{array}{l}\text { - } \text { - The elastic bands on the medial and lateral aspects of the joint. } \\
\text { between } 12 \text { and } 15 \text { days in canine patients. } \\
\text { - Exercise restriction was recommended in all cases, however the } \\
\text { duration of this is not listed. }\end{array}$ \\
\hline Study design: & Retrospective single-centre case series. \\
\hline Outcome studied: & $\begin{array}{l}\text { Outcome assessed subjectively by veterinary assessment and client } \\
\text { reports. Factors considered during assessment include: range of } \\
\text { motion at time of implant removal (in case one and two), limb use } \\
\text { (in case one only), and lameness (in case two only). }\end{array}$ \\
\hline $\begin{array}{l}\text { Main findings: } \\
\text { (relevant to PICO question): }\end{array}$ & $\begin{array}{l}\text { - Case one was considered to have a poor outcome as at nearly } \\
\text { two years following surgery, it is reported that the dog does not } \\
\text { use its operated limb (it is reported as having suffered limb } \\
\text { paralysis with loss of deep pain perception in the operated limb } \\
\text { at the time of injury). Range of motion was limited to } 25^{\circ} \text { at the } \\
\text { time of implant removal. } \\
\text { Case two was considered to have a good outcome. At implant } \\
\text { removal, the patient was lame in the operated forelimb and in } \\
\text { both hindlimbs (the patient suffered concurrent pelvic fractures } \\
\text { at the time of injury), with a range of motion in the operated } \\
\text { forelimb of } 75^{\circ} \text { at the time of implant removal, and } 90^{\circ}\left(140^{\circ} \text { in }\right. \\
\text { contralateral limb) at six weeks following surgery. The patient } \\
\text { was weight-bearing lame at six weeks following surgery, with } \\
\text { the clients reporting increased lameness after exercise, but they } \\
\text { were unable to localise the lameness. }\end{array}$ \\
\hline Limitations: & $\begin{array}{l}\text { - It is a retrospective case series, which sits low on the hierarchy } \\
\text { of evidence. } \\
\text { - Cases are only provided from a single centre. } \\
\text { - } \quad \text { Outcomes are all reported subjectively, including client } \\
\text { reporting. There is limited information on the outcome } \\
\text { measures used, and how they were assessed. Assessment } \\
\text { method varies between patients. } \\
\text { - Time to implant removal was variable, which may have } \\
\text { influenced outcome. } \\
\text { Both dogs with elbow luxation in this study has significant } \\
\text { concurrent injuries (limb paralysis with loss of deep pain } \\
\text { perception in the operated limb caused at the time of injury, and } \\
\text { pelvic fractures with associated lameness, respectively), making } \\
\text { follow-up assessment of the outcome of management of the } \\
\text { elbow luxation difficult. }\end{array}$ \\
\hline
\end{tabular}

\section{Appraisal, application and reflection}

All relevant studies identified and reported above are retrospective case series, which sit low on the hierarchy of evidence. Further to this, they all report on a small number of cases, ranging from just two to 44 (mean 13.8) cases; multiple single case reports were identified during the literature search, but were excluded. Of the nine studies reported, only five have been published since 2000 , and only two have been 
published in the last five years. Since veterinary medicine and surgery is a rapidly developing branch of the medical industry, older studies are sometimes less relevant to the modern practitioner, however it appears that a lot of techniques used in the older reports are still employed today.

Five of the studies report cases that had presented as referrals from primary care veterinary surgeons (the remaining four studies do not state whether they are a referral hospital), which may introduce bias as, it appears, more difficult to manage cases (i.e. more severe injuries/comorbidities) that are inevitably overrepresented at referral centres tend to require surgical management. Because different presentations appear to require different management, it is difficult to compare the success of open reduction (with or without surgical stabilisation) and closed reduction. Overall, the quality of evidence is poor. This limits the ability to generalise the results. However, trends in case management and a rough consensus among authors can be identified, allowing an evidence-based approach to be formulated. Until higher quality evidence (i.e. randomised, controlled, blinded) is available, it is difficult to draw more definitive conclusions. In the available literature, cases of traumatic elbow luxation managed by closed reduction appear to have a better long-term prognosis than cases managed by open reduction and surgical stabilisation. That being said, it is important to consider that the poorer outcome in surgically-managed cases could reflect the severity or chronicity of the injury rather than the treatment method itself, or indeed could reflect a combination of the two.

When considering all the studies listed above, there appears to be a step-by-step approach to management of traumatic canine elbow luxation, outlined most completely by Sajik et al. (2016). Closed reduction should be attempted in all cases as it seems that early, successful closed reduction provides the best long-term prognosis. Stability of the elbow should then be assessed using Campbell's method - this should also help identify which collateral ligaments are injured. Should closed reduction not be possible, or should the elbow continue to be unstable or reluxate after closed reduction, surgical management is indicated. There are multiple surgical techniques described, though the most commonly employed appears to be primary ligament repair with non-absorbable suture, with concurrent placement of bone anchor screws and a figureof-eight wire on the injured aspect(s) of the elbow - a comparison of the efficacy of individual surgical methods was considered beyond the scope of this Knowledge Summary and further research in this area is warranted. Joint immobilisation is widely recommended and commonly employed, however this is quite variable amongst studies with no clear consensus on the type or duration of immobilisation.

In conclusion, in cases of traumatic canine elbow luxation, closed reduction should be attempted in all cases. Surgical intervention is indicated in cases where closed reduction is not possible, or where reluxation or persistent joint instability follows closed reduction. A period of joint immobilisation should follow treatment. A significant proportion of cases in both treatment groups will suffer varying degrees of continued morbidity in the future. When cases can be treated successfully with early closed reduction, prognosis appears to be better than those cases requiring surgical management.

\section{Methodology Section}

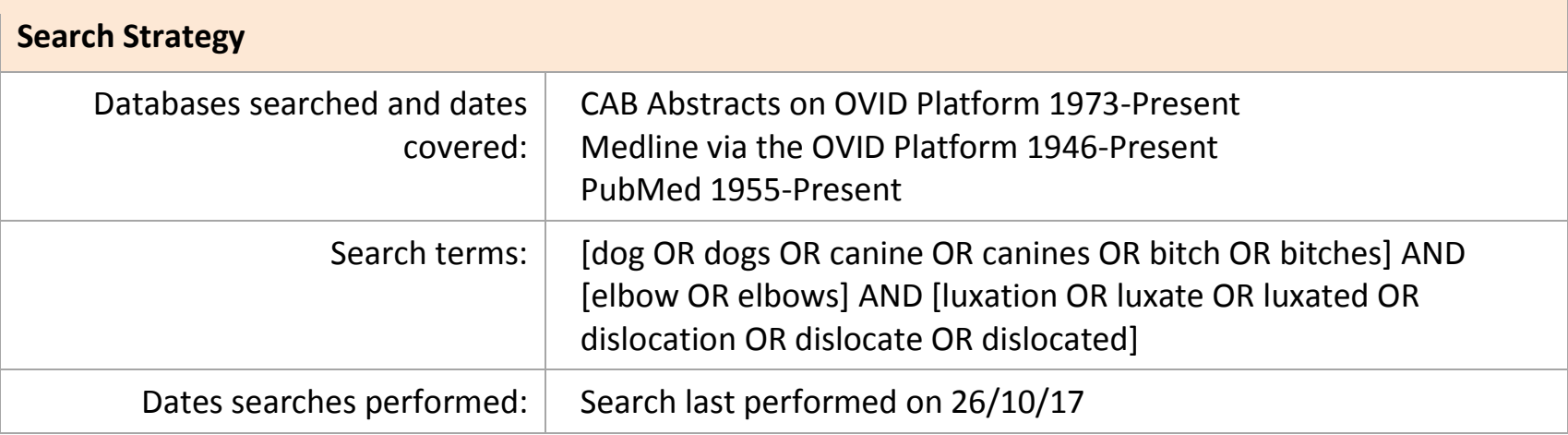




\begin{tabular}{|c|l|}
\hline Exclusion / Inclusion Criteria \\
\hline Exclusion: & $\begin{array}{l}\text { Articles not available in English, single case reports, book chapters, } \\
\text { conference proceedings, articles which were not relevant to the } \\
\text { PICO question. }\end{array}$ \\
\hline Inclusion: & $\begin{array}{l}\text { Articles available in English which were relevant to the PICO. } \\
\text { Articles had to involve more than one animal. Literature reviews } \\
\text { were included. }\end{array}$ \\
\hline
\end{tabular}

\begin{tabular}{|c|c|c|c|c|c|c|c|}
\hline \multicolumn{8}{|c|}{ Search Outcome } \\
\hline Database & $\begin{array}{l}\text { Number } \\
\text { of results }\end{array}$ & $\begin{array}{c}\text { Excluded } \\
\text { - non- } \\
\text { English } \\
\text { language }\end{array}$ & $\begin{array}{c}\text { Excluded } \\
\text { - single } \\
\text { case } \\
\text { report }\end{array}$ & $\begin{array}{l}\text { Excluded } \\
\text { - book } \\
\text { chapter }\end{array}$ & $\begin{array}{l}\text { Excluded - } \\
\text { conference } \\
\text { proceedings }\end{array}$ & $\begin{array}{c}\text { Excluded } \\
- \\
\text { irrelevant } \\
\text { to PICO }\end{array}$ & $\begin{array}{c}\text { Total } \\
\text { relevant } \\
\text { papers }\end{array}$ \\
\hline CAB Abstracts & 138 & 51 & 12 & 3 & 12 & 53 & 7 \\
\hline Medline & 40 & 3 & 5 & 0 & 0 & 27 & 5 \\
\hline PubMed & 62 & 8 & 5 & 0 & 0 & 44 & 5 \\
\hline \multicolumn{6}{|c|}{ Total relevant papers when duplicates removed } & & 9 \\
\hline
\end{tabular}

\section{CONFLICT OF INTEREST}

The author declares no conflict of interest.

\section{REFERENCES}

1. Billings LA, Vasseur PB, Todoroff RJ, Johnson W (1992). Clinical results after reduction of traumatic elbow luxations in nine dogs and one cat. Journal of the American Animal Hospital Association; 28(2): pp137-142.

2. Guzel O, Altunatmaz K, Saroglu M, Aksoy O (2006). Traumatic luxations of the elbow in cats and dogs. Veteriner Fakultesi Dergisi (Istanbul); 32(2): pp31-43.

3. McCartney W, Kiss K, McGovern F (2010). Surgical stabilization as the primary treatment for traumatic luxation of the elbow joint in 10 dogs. International Journal of Applied Research in Veterinary Medicine; 8(2): pp97-100.

4. Mitchell KE (2011). Traumatic elbow luxation in 14 dogs and 11 cats. Australian Veterinary Journal; 89(6): pp213-216. http://dx.doi.org/10.1111/i.1751-0813.2011.00718.x 
5. O'Brien MG, Boudrieau RJ, Clark GN (1992). Traumatic luxation of the cubital joint (elbow) in dogs: 44 cases (1978-1988). Journal of the American Veterinary Medical Association; 201(11): pp1760-1765.

6. Pass MA, Ferguson JG (1971). Elbow dislocation in the dog. Journal of Small Animal Practice; 12(6): pp.327-332. http://dx.doi.org/10.1111/j.1748-5827.1971.tb06237.x

7. Sajik D, Meeson RL, Kulendra N, Jordan C, James D, Calvo I, Farrell M (2016). Multi-centre retrospective study of long-term outcomes following traumatic elbow luxation in 37 dogs. Journal of Small Animal Practice; 57(6): pp422-428. http://dx.doi.org/10.1111/isap.12499

8. Schaeffer IGF, Wolvekamp P, Meij BP, Theijse LFH, Hazewinkel HAW (1999). Traumatic luxation of the elbow in 31 dogs. Veterinary and Comparative Orthopaedics and Traumatology; 12(1): pp33-39.

9. Vedrine B (2017). Use of an elastic transarticular external fixator construct for immobilization of the elbow joint. Canadian Veterinary Journal; 58(4): pp353-359. 


\section{Cinam \\ ochese}

\section{Intellectual Property Rights}

Authors of Knowledge Summaries submitted to RCVS Knowledge for publication will retain copyright in their work, and will be required to grant to RCVS Knowledge a non-exclusive license of the rights of copyright in the materials including but not limited to the right to publish, re-publish, transmit, sell, distribute and otherwise use the materials in all languages and all media throughout the world, and to license or permit others to do so.

\section{Disclaimer}

Knowledge Summaries are a peer-reviewed article type which aims to answer a clinical question based on the best available current evidence. It does not override the responsibility

of the practitioner. Informed decisions should be made by considering such factors as individual clinical expertise and judgement along with patient's circumstances and owners' values. Knowledge Summaries are a resource to help inform and any opinions expressed within the Knowledge Summaries are the author's own and do not necessarily reflect the view of the RCVS Knowledge.

Veterinary Evidence and EBVM Network are RCVS Knowledge initiatives. For more information please contact us at editor@veterinaryevidence.org

RCVS Knowledge is the independent charity associated with the Royal College of Veterinary Surgeons (RCVS). Our ambition is to become a global intermediary for evidence based veterinary knowledge by providing access to information

that is of immediate value to practicing veterinary professionals and directly contributes to evidence based clinical decision-making.

www.veterinaryevidence.org

RCVS Knowledge is a registered Charity No. 230886. Registered as a Company limited by guarantee in England and Wales No. 598443.

Registered Office:

Belgravia House

62-64 Horseferry Road

London SW1P 2AF 